\title{
Can differences in publisher size account for the relatively low prices of the journals available to master's universities through commercial publishers' databases? The importance of price discrimination and substitution effects
}

\author{
William H. Walters ${ }^{1}[0$
}

Received: 1 May 2021 / Accepted: 4 November 2021 / Published online: 1 January 2022

(C) The Author(s) 2021

\begin{abstract}
Using price quotes and invoices for thousands of full-text databases and single-journal subscriptions, this study confirms that for a typical master's university, the journals acquired through commercial publishers' databases cost substantially less than those acquired through the databases of scholarly societies, universities, and other nonprofits. Moreover, the lower prices of commercial publishers' journals cannot be readily attributed to publisher size (number of journals published) or to any of several other explanatory variables. There is a weak, direct association between publisher size and price among the for-profit journals but a stronger, inverse relationship between publisher size and price among the nonprofit journals. These findings, along with the results of previous research, suggest that resource providers may have incentives to keep prices low due to the collection development strategies adopted by many teaching-oriented colleges and universities. If the library's goal is to hold a sufficient number of high-quality journals rather than to provide immediate access to every wanted journal, particular journals and databases may be regarded as substitutes even when each product provides unique content. Many U.S. bachelor's and master's institutions have goals different from those of the major research universities, and commercial publishers (along with some of the larger nonprofits) seem to recognize this when setting and negotiating prices.
\end{abstract}

Keywords Cost $\cdot$ Economies of scale $\cdot$ Journals $\cdot$ Nonprofit $\cdot$ Price discrimination · Substitution

William H. Walters

william.walters@manhattan.edu

1 Mary Alice \& Tom O’Malley Library, Manhattan College, 4513 Manhattan College Parkway, Riverdale, NY 10471, USA 


\section{Introduction}

Faculty and librarians routinely point to commercial publishers as the reason for high journal prices. The largest commercial publishers and their comprehensive journal collections ("big deals") have been singled out for special censure (e.g., Bergstrom, 2001; Larivière et al., 2015; Mongeon et al., 2021; Wenzler, 2017). However, two recent studies reveal that for a typical master's university, commercial publishers' journals cost considerably less, on average, than those available from scholarly societies, university presses, and other nonprofit organizations (Bergstrom et al., 2014; Walters \& Markgren, 2021). Moreover, journals acquired through full-text databases cost less than singlejournal subscriptions even when the total cost of each database is divided only among the wanted journals - those that faculty have identified as important to their teaching and research. (See Table 1 for several key concepts used in this study.)

Table 1 Key concepts in the evaluation of cost per wanted journal

Wanted journals are the journals most important for teaching or research at a particular college or university. At Manhattan College, the wanted journals were identified by the faculty in each department; they include most of the highly cited journals in each subject area as well as other journals that are especially useful for undergraduate instruction

Resource providers are the organizations that make full-text journal resources available to libraries. They include scholarly societies, universities, other nonprofit agencies, commercial publishers, and library vendors. Although most resource providers are publishers, some are not. For instance, library vendors such as EBSCO and ProQuest do not themselves publish journals. Instead, they package and distribute journals from multiple publishers through their own online platforms. Except as specified in the text, commercial publishers' journals are those acquired through commercial publishers. The commercially published journals that appear in the full-text databases of library vendors such as EBSCO and ProQuest are included in the library vendors category

Full-text journal resources are subscriptions or products that provide access to the wanted journals. They include single-journal subscriptions (print or online) as well as full-text databases (i.e., online bundles, packages, aggregations, or collections of journals). Open Access (OA) journals, which are freely available to the general public, can also be counted as full-text journal resources. To "subscribe" to an OA journal, the library makes it available through the same mechanisms used for conventional online journals

Cost, in this context, is the university's expenditure - not the publisher's cost of production. The cost of a journal may refer to the price of a single-journal subscription or to that portion of a database subscription/ license fee that is attributed or allocated to a particular journal within the database

Bundling is the practice of offering a set of online journals as an indivisible product-a full-text collection or database. Bundling is attractive to publishers mainly because their marginal cost of production-the cost of providing access to one more subscriber-is very low in the online environment. With bundling, publishers can maintain or increase their revenue by offering more titles to libraries than the libraries would have been able to acquire (or arguably, would have wanted to acquire) in print. While some "big deal" bundles include all the journals available from a particular publisher, many bundles offer a more limited selection of journals in particular subject areas

Price discrimination is the practice of charging prices that vary from one institution to another based on the institutions' apparent or predicted willingness to pay

Acquisition opportunities arise in response to the fact that most journals can be acquired in more than one way. To gain current access to Northeastern Naturalist, for instance, the Manhattan College library could choose a single-journal subscription from the publisher or subscribe to any of 13 full-text databases offered by BioOne, EBSCO, or ProQuest. That's 14 acquisition opportunities. Likewise, the Journal of Marketing Research corresponds to 10 acquisition opportunities, since it can be acquired as a singlejournal subscription or through any of 9 databases at an annual price ranging from $\$ 288$ to $\$ 795$. Strictly speaking, cost is not an attribute of a particular journal, but of a particular acquisition opportunity 
The results reported by Bergstrom et al. (2014) and Walters and Markgren (2021) are contrary to those of most earlier investigations, a fact that can be traced to their distinctive methods. First, both studies present journal price data for master's institutions. In contrast, most earlier price comparisons relied on data only for doctoral research universities. Second, both include only those journals that have met the selection criteria in place at particular libraries - the journals faculty and librarians actually want for their collections rather than all the journals included or indexed in particular directories or databases. Third, both analyses evaluate not just single-journal subscriptions, but the acquisition opportunities available through full-text databases and other bundled online resources. Finally, both are based on the prices actually paid by academic libraries. That is, they account for the fact that the prices negotiated by library consortia, university systems, and individual institutions are often substantially lower than list price.

For a typical master's university, the commercial/nonprofit price differential is substantial. At Manhattan College, for instance, the journals acquired through commercial publishers' databases have an average cost per wanted journal of $\$ 277$; those acquired through the databases of scholarly societies, universities, and other nonprofits have an average cost per wanted journal of $\$ 542$ (Walters \& Markgren, 2021). Having established that a commercial/nonprofit price differential exists, we might next consider whether it can be attributed to resource provider type per se or to some other key difference between commercial publishers and nonprofits. The most obvious difference between the two groups is that commercial publishers tend to be much larger, based on the number of journals published. ${ }^{1}$ This investigation therefore addresses a key question: Do the differences in average cost per wanted journal, by resource provider type, persist when we control for publisher size and other likely covariates (subject coverage, citation impact, and journal size)?

The current study also sets forth a possible explanation for the price discrimination practiced by commercial publishers (i.e., the fact that the prices charged to master's institutions are substantially lower than those paid by the major research universities). Although each journal and each full-text database offer unique content, particular journals and databases may nonetheless be regarded as substitutes whenever the goal of the library's collectionbuilding efforts is to provide access to an adequate number of wanted journals rather than to every wanted journal. Arguably, this situation prevails at most U.S. bachelor's and master's universities. Within this context, price-sensitive institutions can choose to do without a particular journal (and make credible threats to cancel) whenever they regard the price as too high.

The paper begins with a near replication of the Walters and Markgren (2021) analysis using updated or corrected Manhattan College prices for several databases. (Manhattan College is a university of 4000 students in the Carnegie master's-larger category.) Two descriptive analyses are presented-one in which every wanted journal in a particular database was assigned an equal proportion of the total database cost, and a second analysis in which cost per wanted journal was recalculated to account for the size of each journal (the number of articles per year).

Next, the differences among the various resource provider types are examined, with particular attention to the size and scope of the commercial and nonprofit providers. That discussion is followed by the main empirical analyses-four regressions that evaluate whether

\footnotetext{
${ }^{1}$ As the data compiled for this study reveal, the "average" commercial publisher publishes 526 wanted journals. The averages for universities, scholarly societies, and other nonprofits are 114, 106, and 47, respectively.
} 
the apparent impact of resource provider type on cost per wanted journal persists when we control for publisher size, subject area, citation impact, and journal size. The regressions focus solely on the journals acquired through full-text databases.

The paper concludes with a discussion of the main findings, the issues that remain unresolved, and the ways in which the results of the study might bear on the decisions made by publishers and librarians.

\section{Context and previous research}

\section{Prices of single-journal subscriptions}

Nearly all the journal price studies published since 1989 are based on the list prices of single-journal subscriptions. Without exception, these studies report that commercial publishers' journals cost more than nonprofit journals. Nine comparative studies covering a wide range of subject areas reveal an average price differential of 2.2 for the 1990-1994 period (i.e., commercial publishers' journals cost 2.2 times as much as nonprofits'), followed by a ten-year increase in the differential, then a ten-year decline. Specifically, the nine studies report average price differentials of 2.2 (1990-1994), 2.9 (1995-1999), 3.7 (2000-2004), 2.0 (2005-2009), and 1.3 (2010-2014) (Bergstrom, 2001; Christensen, 1993; Cornell University, 1998; Davis, 2002; Dewatripont et al., 2006; Moghaddam, 2006; RoseWiles, 2011; White \& Creaser, 2004, 2007).

Fourteen other studies have used regression to estimate the independent effect of forprofit status on single-journal subscription prices. Overall, these investigations reveal a similar decline in the extent to which for-profit status is associated with higher prices (Table 2). The decline is relative, however, and the price differential remains considerable. In 2007, for-profit status was associated with an average price differential of $345 \%$; in 2017, 67\% (Dewatripont et al., 2007; Liu \& Gee, 2017). ${ }^{2}$

These same regression analyses also examine the impact of explanatory variables other than publisher type. Table 3 shows the covariates that have been used in two or more of the 14 regression studies. The effects of publisher size and citation impact are discussed later.

\section{Prices of the journals acquired through full-text databases}

Although the investigations shown in Tables 2 and 3 were planned and undertaken with care, all of them are fundamentally flawed. By omitting any consideration of the journals acquired through full-text databases, they fail to account for the primary mechanism by which many academic libraries now acquire scholarly journals. Single-journal subscriptions "[have] long been a declining part of the market, especially for larger publishers, with the vast majority of journals sold as bundles of titles, either directly to libraries or to library consortia" (Johnson et al., 2018, p. 18). Likewise, survey data from the Association of Research Libraries reveal that full-text databases are "the overwhelming strategy" by which research libraries acquire journal content (Strieb \& Blixrud, 2014, p. 594). By 2012, the full-text journal packages of six major publishers-the American Chemical Society,

\footnotetext{
2 The interpretation of the values in Table 2 differs slightly based on whether the dependent variable was entered in natural log form; see the table notes.
} 


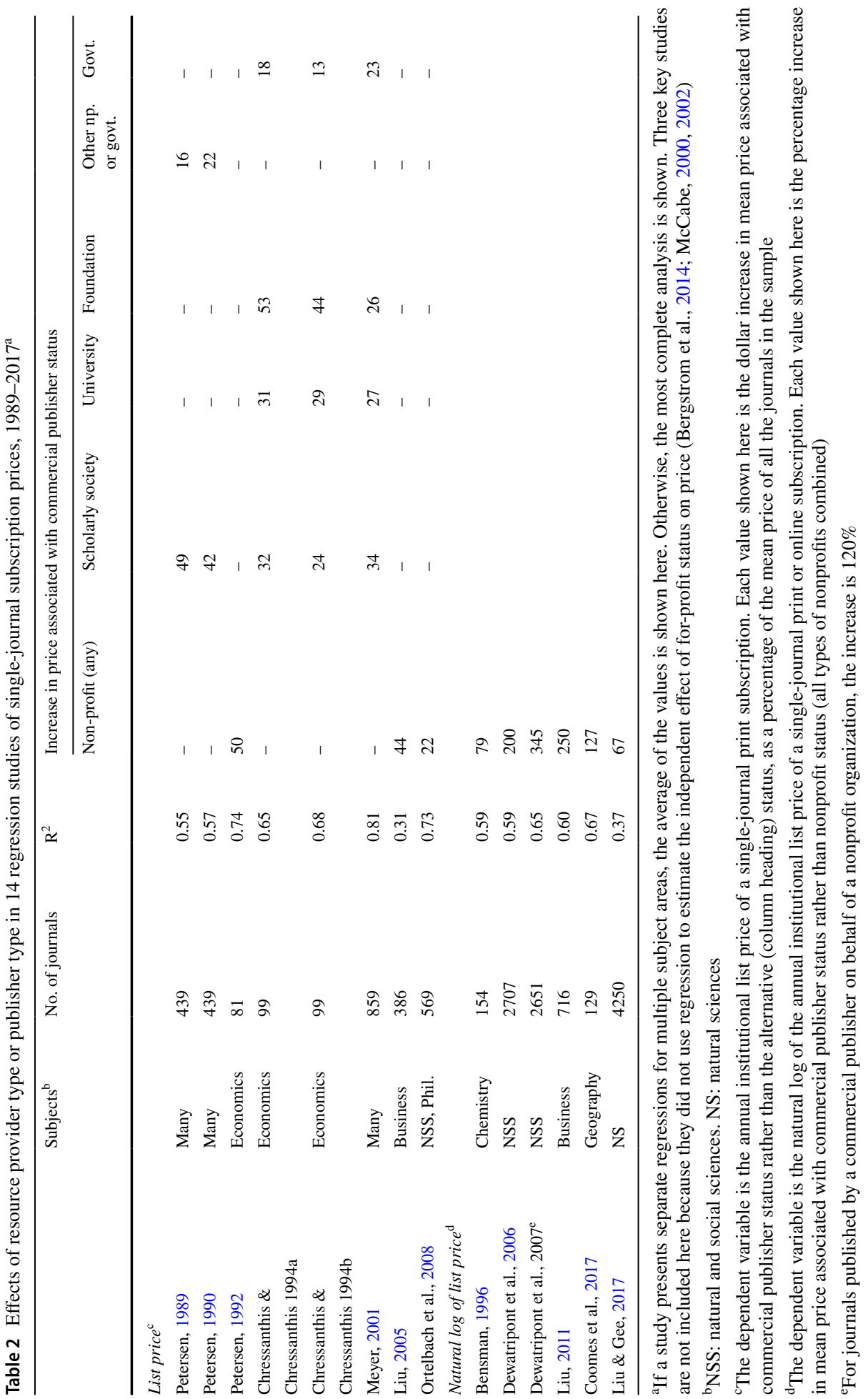


Table 3 Explanatory variables used in more than one of the 14 regression studies of singlejournal subscription prices, 1989-2017, with the number of times each relationship was reported $^{\mathrm{a}}$

\begin{tabular}{llll}
\hline & $\begin{array}{l}\text { Directly } \\
\text { related to } \\
\text { price }\end{array}$ & $\begin{array}{l}\text { Inversely } \\
\text { related to } \\
\text { price }\end{array}$ & $\begin{array}{l}\text { Unre- } \\
\text { lated to } \\
\text { price }^{\mathrm{b}}\end{array}$ \\
\hline Physical sciences & 5 & 0 & 0 \\
Life sciences & 3 & 0 & 2 \\
Physical and life sciences & 1 & 0 & 1 \\
Social sciences & - & - & - \\
Other subject areas & 0 & 0 & 2 \\
Publisher size & 2 & 0 & 0 \\
Citation impact of the journal & 3 & 0 & 2 \\
Citations per article & 0 & 1 & 2 \\
Journal size: issues per year & 7 & 0 & 2 \\
Journal size: articles per year & 5 & 0 & 0 \\
Journal size: pages per year & 5 & 0 & 0 \\
Circulation or library holdings & 0 & 5 & 0 \\
Age: years since founding & 1 & 6 & 5 \\
Accepts advertising & 0 & 2 & 7 \\
Has substantial illustrations & 2 & 0 & 6 \\
Personal subscription price & 3 & 0 & 0 \\
Published in English & 2 & 0 & 0 \\
Publisher based in the U.S & - & 0 & 3 \\
Publisher based in the U.K & 6 & 5 & 0 \\
Publisher based in Europe & 5 & 0 & 0 \\
Publisher based elsewhere & 1 & 0 & 0 \\
\hline
\end{tabular}

${ }^{a}$ Excludes resource provider type and publisher type, which are shown in Table 2

${ }^{\mathrm{b}}$ Not a statistically significant relationship ( $p<0.05$, two-tailed), for studies based on a sample of journals

Elsevier, Nature, Sage, Springer, and Wiley—were each held by at least $86 \%$ of ARL member institutions.

Two developments, bundling and price discrimination, have dramatically altered the journal landscape in recent decades (Björk, 2021; McCabe, 2013). (See Table 1.) A simple form of price discrimination-personal versus institutional subscription rates-was widespread even in the print environment, and most publishers now practice more sophisticated forms of price discrimination based on institutional characteristics such as enrollment, Carnegie classification, number of faculty or students in particular subject areas, library acquisitions budget, or prior expenditures on the publisher's journals. Moreover, many libraries pay less than the standard rates due to their negotiation of multi-year deals, their willingness to maintain subscriptions to other products from the same company, their participation in regional consortia that reduce transaction costs, and their demonstrated willingness to cancel subscriptions if vendors do not agree to their terms. A typical condition of these arrangements is that the universities agree not to disclose the prices they have paid for particular online resources.

Nonstandard pricing and confidential agreements have led to the use of single-journal list prices in many empirical analyses even though single-journal subscriptions account for 
relatively few of the journals held by most academic libraries (Bosch et al., 2020; Coomes et al., 2017; Liu \& Gee, 2017). Just two studies have compared for-profit and nonprofit journal prices using data for full-text databases and collections.

In the first of these studies, Bergstrom et al. (2014) relied on Freedom of Information Act requests to construct a unique data source - a set of license agreements involving more than 160 public universities, six commercial publishers (Elsevier, Emerald, Sage, Springer, Taylor \& Francis, and Wiley), and three nonprofits (the American Chemical Society, Cambridge University Press, and Oxford University Press). Using data for a range of institutional characteristics, they estimated the prices paid by U.S. universities for the "big deal" journal packages of the nine publishers. They also estimated the prices paid for various journal packages under the tiered pricing schedules of 16 additional scholarly societies and university presses.

The data presented by Bergstrom et al. show that for the 151 research universities in the Carnegie R1 category, the average cost of an article in a commercial publisher's database is 2.2 times that of an article in a scholarly society or university press database. The situation is different for the institutions outside the R1 group, however. For the 105 universities in the R2 category, the average cost of an article in a commercial publisher's database is $10 \%$ less than that of an article in a society/university database. For the 591 master's universities, it is $60 \%$ less. $^{3}$ That is, commercial publishers charge relatively high prices when dealing with the major research universities but relatively low prices when dealing with R2 and master's institutions. Although Bergstrom et al. do not present data for other types of postsecondary institutions, it seems reasonable to assume that the commercial/nonprofit price differentials for bachelor's colleges and universities are similar to those for the master's universities. If that is the case, and if the average values hold across the institutions in each category, we can conclude that commercial publishers' databases have a lower cost per article than nonprofit databases at more than $90 \%$ of all four-year U.S. colleges and universities (National Center for Education Statistics, 2021).

The second study to include data for full-text databases is based on the set of wanted journals identified by the faculty of Manhattan College (Walters \& Markgren, 2021). The 2717 wanted journals represent 9017 acquisition opportunities— 9017 mechanisms by which particular wanted journals might be acquired. (See Table 1.) Walters and Markgren obtained realistic price information (price quotes or invoices) for hundreds of databases and single-journal subscriptions, then calculated the cost per wanted journal for each acquisition opportunity. For the journals acquired through full-text databases, cost per wanted journal was calculated as the total database price divided by the number of wanted journals in the database. Unwanted journals were therefore assigned no value and had no bearing on the outcome of the analysis.

The Manhattan College data reveal that for all resource provider types, the average cost of a single-journal subscription is 4.5 times that of a journal acquired through a fulltext database. Of the journals acquired through databases, the most costly are those of the scholarly societies, with an average price 3.3 times that of the commercial publishers'

\footnotetext{
3 These summary statistics are based on the averages of the six commercial publisher values reported by Bergstrom et al. (2014, Appendix Table SI 17), weighted by the number of journals from each publisher. If we consider average cost per citation rather than average cost per article, the results are somewhat different: for R1 universities, the average cost of an article in a commercial publisher's database is 5.8 times that of an article in a scholarly society or university press database; for R2 universities, the differential is 2.3 ; for master's universities, the average cost of an article in a commercial publisher's database is $10 \%$ less than that of an article in a society/university database.
} 
journals. The price differentials for the other resource provider types are lower- 1.5 for universities, 1.2 for library vendors, and 1.0 for other nonprofits such as Project MUSE and BioOne-but no group has an average cost lower than that of the commercial publishers. The differentials in median price are somewhat higher: 3.8 (scholarly societies), 3.1 (universities), 2.8 (library vendors), and 1.7 (other nonprofits).

As Bergstrom et al., (2014, p. 9429) have noted, "Commercial publishers reduce their bundle prices to schools classified as master's institutions much more sharply than do the nonprofits." This makes sense from the perspective of the commercial publishers, who presumably recognize that greater discounts must be offered to the subscribers most likely to cancel online resources in the event of financial difficulties or changing priorities. An institution such as Manhattan College may well be able to cancel the more specialized journals and frame the decision in terms that the faculty will understand (e.g., teaching mission, limited resources, outrageous prices, and greedy commercial publishers). In contrast, major universities must try harder to maintain access to every journal regarded as important by any department or research group.

\section{Publisher size and journal prices}

Conventional economic theory suggests that publishers with a greater share of the market for a particular product will be able to reduce competition and charge higher prices than would otherwise prevail. McCabe (2000), among others, provides evidence that such a relationship should be expected, at least in the print environment. Using data for 990 biomedical journals, he found that two prominent mergers, Elsevier-Pergamon and KluwerLippincott, were associated with price increases of up to $30 \%$ (in addition to the baseline increase of 140\%) over the 1988-1998 period. McCabe explains that because relative cost is central to libraries' acquisition decisions, publishers who control a high proportion of the wanted journals in a particular subject area can increase the prices of those journals all at once, leading to a systemwide increase in prices without a proportional increase in the relative cost of any one title. Subsequent papers have discussed the implications for publishers and libraries (McCabe, 2001) and confirmed these findings using a different analytical approach (McCabe, 2002).

A direct relationship between publisher size and cost per wanted journal would support McCabe's assertion. Although his findings have been used to explain how commercial publishers' market power allows them to charge higher prices, the same argument might be applied to any large publisher. While only commercial publishers seek to maximize profit, it is not difficult to imagine scenarios in which nonprofits - especially scholarly societiesmight give priority to goals other than scholarly communication, such as funding worthy research projects, supporting new investigators, hosting conferences, developing teaching materials, awarding scholarships, recognizing top scholars and practitioners, promoting diversity, supporting the work of other organizations that provide essential but specialized services, purchasing property in order to minimize future expenditures, improving employee compensation within their own organizations, and increasing financial reserves in order to promote organizational stability (Johnson \& Fosci, 2015; Morris, 2005; Robinson, 2011; Waltham, 2010).

There is also a second possibility - that the larger publishers can charge lower prices because they are better positioned to take advantage of global economies of scale. For example, they may be able to standardize copyediting and web site maintenance procedures for many journals all at the same time, or to establish large-scale operations in cities where 
labor costs are low. Likewise, they may be able to maintain high revenue not by charging more for comparable journals, but by modifying their journal portfolios and services more rapidly or more fully in response to changes in demand. For instance, the larger publishers may be more aggressive in developing or acquiring new journals in rapidly growing research areas, improving their online interfaces, developing new information products, and shutting down journals or functions that no longer support their goals. (Of course it is possible that these activities will reduce production costs in the long term but increase them in the short term-e.g., in the years immediately after a merger.) Finally, larger publisher may be better able to maintain the infrastructure needed to evaluate their pricing and marketing strategies on a continuous basis, to negotiate complex or flexible arrangements with particular customers, and to practice price discrimination (Table 1) in ways that benefit both the resource provider and the subscribing institution. In contrast, smaller publishers may not have the staff or expertise needed to pursue these options in a systematic way.

If commercial publishers are able to charge less because they are larger, then nonprofits might also be able to reduce their prices by publishing more journals. Although the current study does not evaluate this possibility directly, we can conclude that our evidence is consistent with the "economies of scale" explanation if three conditions are met: (1) commercial publishers are larger than the others, (2) the larger publishers tend to charge lower prices than the others, and (3) the apparent impact of resource provider type declines when publisher size is added to the regression model. ${ }^{4}$

Economies of scale can perhaps explain why larger publishers might be able to charge less, but they cannot explain why publishers would choose to do so-why they would lower prices when faced with relatively little competition. One possible answer lies in the extent to which individual journals or databases can be regarded as substitutes. Björk (2021) and Plasmeijer (2002) have argued that the main determinant of journal prices is libraries' willingness to pay- that the real consumers (faculty and students) are indifferent to the prices paid by their agents (librarians), and that librarians, in turn, will sometimes rather pay higher prices than face complaints from faculty and students. This reasoning is valid, as far as it goes, but both Björk and Plasmeijer also assume that the library's goal is to provide access to every wanted journal. "Libraries at bigger universities must cater to the needs of scholars and teachers from many fields and consequently will meet internal resistance from faculty if they try, for cost reasons, to refuse one of the big deals of the leading publishers" (Björk, 2021, p. 181). This may be true at the top research universities. For many other colleges and universities, however, the goal is not to ensure access to every wanted journal, but to provide a collection of high-quality journals that is "good enough" for faculty and students who understand that immediate access to all the best journals is not always feasible. For example, the latest Manhattan College serials review was a deliberate attempt to obtain a critical mass of wanted journals in the most cost-effective way (Walters \& Markgren, 2020). There was never any prospect of getting every wanted journal. In much the same way, faculty at master's universities may accept the existence of financial constraints on library resources just as they routinely accept similar constraints

\footnotetext{
4 Any link between publisher size and cost per wanted journal is most likely to be apparent in the data for the journals provided through full-text databases. We should not necessarily expect a similar relationship for single-journal subscriptions, since we cannot assume that each journal "pays its own way" with regard to production costs and revenue. Likewise, the complex business models of library vendors such as EBSCO and ProQuest make it difficult to examine the relationships between production cost, revenue, and price in a straightforward way.
} 
in other areas of their work. Recent survey evidence shows that faculty do not necessarily assume that their own university libraries can supply everything they want, and that they are perfectly willing to "beg, borrow, and steal" in order to get what they need (Walters, 2019). Finally, some full-text databases are marketed and widely recognized as substitutes for one another in terms of content, intended purpose, and intended audience. For instance, ProQuest Central and EBSCO Academic Search Complete are both large, multidisciplinary databases intended for undergraduates, and some libraries have been known to switch back and forth between the two based on small differences in cost per download. For many teaching-oriented universities, no journal is essential, and publishers seem to recognize this when setting their prices.

Previous studies provide limited support for McCabe's (2000, 2001, 2002) assertion that larger publishers face reduced competition and can therefore charge higher prices. Just two regression studies have included publisher size as an explanatory variable (Table 3), and both revealed strong, direct relationships between publisher size and price (Coomes et al., 2017; Ortelbach et al., 2008). Both studies were based on single-journal subscription prices, however, and neither accounted for the bundling and price discrimination that prevail within the current environment. Moreover, publisher size had no impact on cost in a separate regression that included just the nonprofit publishers (Ortelbach et al., 2008).

\section{Methods}

As described in this section, the calculation of cost per wanted journal required the identification of 2717 wanted journals based on the assessments of the Manhattan College faculty; the compilation and refinement of a list of full-text journal resources that might provide access to those journals; the collection of price information for every full-text journal resource; the determination of the number of wanted journals within each resource; and the calculation of cost per wanted journal for every acquisition opportunity. These procedures correspond to steps 1, 3, 4, and 5 of the Manhattan College serials review process, which is described fully elsewhere (Walters \& Markgren, 2020).

\section{Identifying wanted journals}

In February 2018, the 36 Manhattan College department chairs were asked to work with their faculty to identify the journals most important for their teaching and research. The faculty were supplied with journal lists, citation information, and subjective journal ratings from Journal Citation Reports (JCR) and the Excellence in Research for Australia (ERA) project (Australian Research Council, 2010; Clarivate Analytics, 2018; Graham, 2008; Lamp, 2010), and they were encouraged to add important journals not found on the JCR and ERA lists. Local holdings information and use statistics were not provided, however, since that information might have led to bias in favor of the journals initially held by the library. The number of wanted journals to be chosen by each department was set at either (a) 0.314 times the number of journals in the appropriate JCR subject categories or (b) the number of ERA journals rated $A^{*}$ plus 0.7 times the number of journals rated $A$. (Data for the subject areas included in both JCR and ERA reveal that these two standards are roughly equivalent.) Because some faculty felt strongly that the initial selection targets varied too much among departments, the library established a departmental minimum of 30 
journals and a maximum of 200 journals. In addition, the five departments with fewer than 15 undergraduate students (majors) were each assigned an upper limit of 40 journals.

Approximately two-thirds of the chairs solicited journal lists from a subset of their faculty-individuals representing diverse subfields and competing research perspectives, for instance - then combined the results into a single journal list based on the number of faculty who chose each journal. A few of the chairs held meetings in which the faculty worked together to reach a consensus, and a few used other methods such as consulting with the faculty most likely to be interested in the project. Some departments identified slightly more or slightly fewer journals than they were asked to choose, and these modest deviations from the selection targets were allowed. Overall, the chairs were sent information on 14,331 journals. They returned a set of 2717 wanted journals, including 166 OA journals and 209 that did not appear on the JCR and ERA lists. Although wanted/not-wanted status is only moderately correlated with citation impact, the faculty in most departments did select the highest-impact journals in their fields. That is, high citation impact is a good indicator of wanted status even though the relationship between impact and wanted status grows weaker at lower levels of the journal hierarchy (Walters \& Markgren, 2019).

\section{Compiling journal title lists for full-text journal resources}

The Overlap Analysis function of ProQuest 360 Core was used to identify the full-text journal resources that provided current access (with an embargo period of six months or less) to each of the 2717 wanted journals. Purely bibliographic databases and online resources devoted primarily to content other than scholarly journal articles-e-books, popular magazines, and statistical data, for instance-were not included.

More than 10,000 online resources are available to academic libraries. Ideally, we would be able to identify the wanted journals included in each of them. Unfortunately, an analysis of that scope cannot be undertaken in 360 Core, so it was necessary to first exclude the resources unlikely to be appropriate for Manhattan College. Databases were excluded if they provided access to fewer than three wanted journals, if they had fewer than ten wanted journals and the wanted journals comprised less than $3 \%$ of the journals in the database, if they were not available for acquisition by Manhattan College, if they were obviously intended for other kinds of libraries (e.g., middle school libraries or hospital libraries), or if they were clearly less appropriate than other, very similar resources (e.g., if a database was identical to another except for its inclusion of unwanted e-book content). Together, these criteria reduced the number of databases to just 284 .

\section{Compiling price data}

Price data were compiled as part of a comprehensive serials review at Manhattan College. Beginning in November 2018, the library staff contacted resource providers and consortia to compile price information for each of the 284 databases. In nearly all cases, we followed the same procedures used in the acquisition of new databases. If the vendor wanted clarification of our intentions, we provided an overview of the project and made it clear that the results of the exercise would be used to make actual selection decisions. Our inquiries and negotiations led to the revision of the online resource list - the addition of 8 new resources and the removal of 55 based on the criteria presented in the previous step. Despite some difficulties, we were able to obtain price information for all but one of the 237 databases remaining on the list. Each price accounts for any consortial discounts, negotiated 
institutional discounts, or deals offered by resource providers during the price-checking process. Due to price updates and corrections (e.g., resource providers who misinterpreted what we had asked for), a few of the database prices are different from those used in previous studies (Walters \& Markgren, 2020, 2021). Altogether, the prices of seven full-text databases were modified by more than $5 \%$, and smaller changes were made in the prices of six other databases.

We also compiled the prices of single-journal subscriptions to 1901 of the 2717 wanted journals. ${ }^{5} \mathrm{~A}$ few of the wanted journals were available to libraries only through package deals. Moreover, we did not ask for the single-journal subscription prices of Springer or Elsevier journals since we knew from prior inquiries that our package deals offered significantly better pricing.

Due to difficulties encountered during the data compilation process, the final data do not include reliable information on the exact subscription period for each resource. About $45 \%$ of the prices are for the 2019 calendar year, about $45 \%$ are for 2020 , and about $10 \%$ are for other twelve-month periods such as the 2019-20 fiscal year. However, there is no reason to believe that the date coverage is biased with regard to resource provider type or subject area.

\section{Calculating cost per wanted journal}

The price comparisons presented here are based on cost per wanted journal (i.e., cost per acquisition opportunity). Altogether, the 2717 wanted journals represent 9168 acquisition opportunities: 1901 single-journal subscriptions, 168 OA journals acquired individually, and 7099 instances in which a wanted journal is included in one of the 236 full-text databases for which price data were compiled. ${ }^{6}$

For single-journal subscriptions, the cost per wanted journal is the annual online-only subscription price. For OA journals, the cost per wanted journal is $\$ 0$. For the journals acquired through full-text databases, the cost per wanted journal is based on three factors: the database price, as reported by resource providers and library consortia; the number of wanted journals within the database, as determined using the Overlap Analysis function of 360 Core; and the number of articles published within each wanted journal in 2019, as reported by JCR.

In two previous investigations, cost per wanted journal was calculated as the total database price divided by the number of wanted journals in the database (Walters \& Markgren, 2020, 2021). All the journals in a particular database were assigned the same cost, regardless of how many articles they published. That approach is not realistic, however, since journal size varies considerably. In 2019, for instance, the wanted journals in the Wiley Online Library Full Collection ranged in size from 8 articles per year (International Labour Review) to 1863 (Journal of Cellular Biochemistry). It therefore seems reasonable

\footnotetext{
${ }^{5}$ Unfortunately, 150 of the 1901 single-journal subscriptions were inadvertently omitted from an earlier study (Walters and Markgren 2021). The current analysis includes all of them, as does Walters and Markgren (2020).

${ }^{6}$ Although Open Access journals are freely available without a subscription, not all are acquired by libraries. The acquisition of an OA journal is the decision to make it available on the same basis as the library's subscribed journals - to include it in the list of journal holdings and to facilitate access by maintaining links within the library's catalogs and bibliographic databases. OA journals are also included in many full-text databases.
} 
to account for journal size when apportioning the total database cost among the wanted journals in each database.

Because article counts were not available for most of the journals in the arts and humanities $(\mathrm{A} \& \mathrm{H})$ subject category, those journals could not be included in the cost calculations for databases. A\&H journals are therefore excluded from most of the analyses presented here. Moreover, the OA journals included in the full-text databases were each assigned a cost of $\$ 0$, since those journals are freely available whether or not the database is acquired. For the remaining journals included in full-text databases, cost per wanted journal was calculated as (total cost of the database) $\times$ (proportion of the wanted journals in the database that are not $A \& H$ or $O A$ journals $) \times($ proportion of the non- $A \& H$, non-OA wanted-journal articles in the database that were published in the journal). Like the simpler procedure of dividing total database cost by the number of wanted journals, this calculation method ensures that no value or credit is assigned to journals not on the wanted list. It therefore addresses a legitimate criticism - that most full-text databases include a substantial number of journals that do not meet libraries' usual selection standards (Murphy, 2008; Nabe \& Fowler, 2015; Quinn, 2001; Shu et al., 2018; Strieb \& Blixrud, 2014; Walters, 2016).

\section{Explanatory variables}

In each of the four regressions, the dependent variable is cost per wanted journal (mean $=462 ; \mathrm{SD}=1432$ ). This variable was entered in natural $\log$ form (mean $=5.083$; $\mathrm{SD}=1.635$ ) in order to ensure the normality of the regression residuals.

Six explanatory variables, or sets of variables, were used in the descriptive analyses and the regressions. The acquisition mechanism, resource provider type, and publisher size variables were selected due to their conceptual importance. The others are control variables included due to their likely impact on journal cost, as shown in previous research (Table 3). That is, they are included in the regressions so that we can disentangle their effects from the independent effects of resource provider type and publisher size.

1. Acquisition mechanism indicates whether the acquisition opportunity represents a singlejournal subscription, a journal acquired through a full-text database, or an OA journal acquired separately.

2. Resource provider type (scholarly society, university, other nonprofit, commercial publisher, or library vendor) refers to the acquisition opportunity rather than the journal itself. The resource provider may or may not correspond to the journal publisher, since library vendors' databases often provide access to the journals of multiple publishers. The university category consists mainly of university presses, although it also includes academic departments and research centers. The other nonprofit category includes organizations such as Project MUSE and BioOne. The library vendor category includes firms such as EBSCO and ProQuest. Journals published jointly by a scholarly society and a commercial publisher were counted in the commercial publisher category unless the society maintained a web site where the full text of the journal was available.

3. Publisher size is the number of wanted journals associated with the publisher (rather than the resource provider), including those of subsidiary imprints. For the set of acquisition opportunities included in the regressions, the mean is 353 and the SD is 270.

4. Subject area (engineering, physical sciences, business, social sciences, life sciences, education, or arts and humanities) corresponds to the Manhattan College department(s) that identified the journal as a wanted journal. Ten percent of the wanted journals were 
identified by departments in more than one broad subject area and were therefore assigned to multiple subject categories.

5. JIF percentile, obtained from JCR, is the 2019 Journal Impact Factor (JIF) expressed as a percentile score within the relevant JCR subject category (mean=60; $\mathrm{SD}=29$ ). If the journal appeared in multiple subject categories, the scores were averaged. Because JIF is independent of journal size, it represents the average citation impact of an article in the journal rather than the impact of the journal as a whole (Walters, 2017).

6. Journal size is the number of citable items published in 2019 , as reported by JCR (mean=157; SD=362). Citable items include those with a designation of article, review (i.e., comprehensive literature review—not a book review), or proceedings paper. They exclude announcements, book reviews, corrections, editorials, letters, and similar contributions.

\section{Missing values}

Two of the explanatory variables, journal size and JIF percentile, are available only for the journals listed in JCR. Consequently, those variables have missing values for 2163 of the 9168 acquisition opportunities. Because the missing values are concentrated among two types of journals-A\&H journals and OA journals-those two groups are excluded from the regression analyses. There are no missing values for any of the other variables.

The first table in the Results section presents a near-replication of a previous descriptive analysis (Walters \& Markgren, 2021). Because it relies on the original method of calculating cost per wanted journal, that first analysis includes all 9168 acquisition opportunities. A second descriptive analysis, also shown in the first table, uses the new method of calculating journal cost and therefore requires data on journal size. That second analysis includes the 5905 acquisition opportunities not associated with A\&H journals or OA journals.

The other analyses and tables, including the regressions, are based on the 4529 acquisition opportunities that remain when A\&H journals, OA journals, and single-journal subscriptions are excluded. Those 4529 acquisition opportunities includes just 258 cases with missing values. For those cases, journal size and JIF percentile were estimated based on the assumption that the journals not listed in JCR are similar to the lower-impact journals listed in JCR. Each missing value was replaced with the average value for the wanted journals in the lowest $20 \%$ of the JIF distribution within the appropriate subject area: engineering, physical sciences, life sciences, business, social sciences, or education.

\section{Regression analyses}

As noted in the Introduction, this study uses regression analysis to evaluate whether the apparent impact of resource provider type on cost per wanted journal is an independent effect-whether it persists when we control for publisher size, subject area, citation impact, and journal size.

All four regressions focus solely on the journals acquired through full-text databases. $\mathrm{A} \& \mathrm{H}$ journals and OA journals were excluded due to missing values for journal size and JIF percentile. Likewise, single-journal subscriptions were excluded due to the absence of title-by-title price data for the 613 individual journals available through Elsevier and 
Springer. The omission of those two publishers would be likely to bias the results of any analysis of single-journal subscriptions.

Regression Model 1 includes journals from both commercial and nonprofit providers but uses only two sets of independent variables - those representing resource provider type (scholarly society, university, other nonprofit, commercial publisher, or library vendor) and subject area (engineering, physical sciences, business, social sciences, life sciences, or education). In contrast, Model 2 incorporates the full set of explanatory variables: resource provider type, subject area, publisher size, JIF percentile, and journal size.

As described in the Results section, two additional regressions may help further clarify the relationships between publisher size and journal prices. Model 3 uses the full set of explanatory variables but evaluates their impact only for the acquisition opportunities offered by the for-profit resource providers (commercial publishers and library vendors). Model 4 also uses the full set of variables but is limited to the nonprofit providers (scholarly societies, universities, and other nonprofits).

Alternative specifications of the regression models revealed no nonlinear relationships between cost per wanted journal (in natural log form) and any of the explanatory variables. Normal probability plots showed a roughly normal distribution of the regression residuals. Likewise, there were no signs that multicollinearity was a problem. For Model 1, the highest variance inflation factor was 1.3 (scholarly society) and the average VIF was 1.1. For Model 2, the highest VIF was 2.2 (publisher size) and the average was 1.4.

Because the regression data include the entire population of interest, $t$ tests are neither valid nor necessary as tests of statistical significance. Nonetheless, the B coefficients significant at the 0.05 level (two-tailed) are marked with asterisks in the tables simply to indicate that the coefficients are high relative to the associated standard errors.

\section{Descriptive results and discussion}

Table 4 shows how cost per wanted journal varies by acquisition mechanism, resource provider type, and subject area. The left side of the table is based on the same cost calculation method used in an earlier study (Walters \& Markgren, 2021). That is, the total price of each database was divided equally among the wanted journals in the database. Because updated and corrected price data were used in this investigation, the Table 4 values are slightly different from those reported earlier. The differences are modest, however, and the use of corrected data does not alter the principal findings of the previous study.

The right side of Table 4 uses the new calculation method, which accounts for journal size when apportioning the total database cost among the wanted journals in each database. As Table 4 shows, the new method has two overall effects. First, by excluding the A\&H journals and the OA journals (see the Methods section), it increases the overall mean cost per wanted journal ("All journals") by $37 \%$. Second, by apportioning database cost in proportion to journal size, it substantially increases the prices of the largest journals (of which there are few) while slightly reducing the prices of the other journals (of which there are many). For the journals acquired through full-text databases, this results in a $30 \%$ increase in mean cost but a $21 \%$ decrease in median cost.

Despite these changes, the relative differences in cost among the various types of journals are comparable regardless of which calculation method is used. Likewise, most of the differences among groups (e.g., provider types and subject areas) are readily apparent 
Table 4 Cost per wanted journal, by acquisition mechanism, resource provider type, and subject area

\begin{tabular}{|c|c|c|c|c|c|c|c|c|}
\hline & \multicolumn{4}{|c|}{ Original calculation method ${ }^{\mathrm{a}}$} & \multicolumn{4}{|c|}{ New calculation method ${ }^{b}$} \\
\hline & Median & Mean & SD & $\mathrm{n}$ & Median & Mean & $\mathrm{SD}$ & $\mathrm{n}$ \\
\hline All journals & 249 & 567 & 1391 & 9168 & 262 & 774 & 1899 & 5905 \\
\hline \multicolumn{9}{|l|}{ Acquisition mechanism } \\
\hline Single-journal subscription & 714 & 1406 & 2401 & 1901 & 983 & 1803 & 2710 & 1376 \\
\hline Full-text database & 207 & 355 & 845 & 7099 & 164 & 462 & 1432 & 4529 \\
\hline Open Access journal & 0 & 0 & 0 & 168 & - & - & - & 0 \\
\hline \multicolumn{9}{|l|}{ Resource provider type } \\
\hline Scholarly society & 612 & 1298 & 2245 & 849 & 646 & 1363 & 2570 & 806 \\
\hline University & 343 & 458 & 601 & 868 & 371 & 677 & 1040 & 383 \\
\hline Other nonprofit & 168 & 311 & 519 & 503 & 358 & 618 & 936 & 156 \\
\hline Commercial publisher & 161 & 641 & 1729 & 4062 & 152 & 732 & 2085 & 3274 \\
\hline Library vendor & 284 & 344 & 247 & 2718 & 316 & 559 & 807 & 1286 \\
\hline \multicolumn{9}{|c|}{ Single-journal subscriptions, by resource provider type } \\
\hline Scholarly society & 993 & 1715 & 2708 & 412 & 1116 & 1822 & 2765 & 386 \\
\hline University & 236 & 420 & 742 & 491 & 452 & 765 & 1131 & 178 \\
\hline Other nonprofit & 123 & 501 & 881 & 59 & 304 & 910 & 1136 & 28 \\
\hline Commercial publisher $^{\mathrm{c}}$ & 1009 & 1842 & 2709 & 939 & 1118 & 2062 & 2909 & 784 \\
\hline Library vendor & - & - & - & 0 & - & - & - & 0 \\
\hline \multicolumn{9}{|c|}{ Journals in full-text databases, by resource provider type } \\
\hline Scholarly society & 376 & 905 & 1603 & 437 & 302 & 941 & 2301 & 420 \\
\hline University & 362 & 506 & 333 & 377 & 305 & 601 & 950 & 205 \\
\hline Other nonprofit & 168 & 285 & 445 & 444 & 384 & 554 & 879 & 128 \\
\hline Commercial publisher & 110 & 280 & 1057 & 3123 & 94 & 314 & 1524 & 2490 \\
\hline Library vendor & 284 & 344 & 247 & 2718 & 316 & 559 & 807 & 1286 \\
\hline \multicolumn{9}{|l|}{ Subject area } \\
\hline Engineering & 356 & 922 & 2290 & 810 & 442 & 1146 & 2576 & 710 \\
\hline Physical sciences & 301 & 915 & 1843 & 1624 & 365 & 1223 & 2281 & 1219 \\
\hline Life sciences & 262 & 756 & 1903 & 1130 & 325 & 1083 & 2915 & 811 \\
\hline Business & 287 & 557 & 1412 & 1165 & 229 & 605 & 1540 & 1102 \\
\hline Social sciences & 262 & 446 & 839 & 2511 & 209 & 449 & 755 & 2170 \\
\hline Education & 206 & 410 & 703 & 650 & 154 & 398 & 617 & 539 \\
\hline Arts and humanities & 168 & 278 & 290 & 2241 & - & - & - & 0 \\
\hline
\end{tabular}

${ }^{\mathrm{a}}$ The journals in full-text databases were each assigned an equal proportion of the total database cost. These data include all 9168 acquisition opportunities, although Open Access journals (those acquired separately rather than through databases) are not included in the statistics for resource provider types

${ }^{\mathrm{b}}$ For the journals in full-text databases, cost per wanted journal was recalculated to account for the number of articles in each journal; see Calculating cost per wanted journal in the Methods section of the text. These data include the 5905 acquisition opportunities not associated with Open Access journals or journals in the arts and humanities category

${ }^{\mathrm{c}}$ The data for single-journal subscriptions from commercial publishers may be biased due to the exclusion of certain Elsevier and Springer journals; see Regression analyses in the Methods section of the text

regardless of whether median or mean values are considered. Henceforth, the discussion focuses on the values that result from the new calculation method. 


\section{Differences in cost by acquisition mechanism, resource provider type, and subject area}

As shown in Table 4, the new results confirm a key finding of Walters and Markgren (2021); the median cost of a single-journal subscription is nearly six times that of a journal acquired through a full-text database. A title-by-title price comparison for the wanted journals available through both single-journal subscription(s) and full-text databases(s) reveals the same relationship. There are 1129 such journals but only 108 for which a single-journal subscription is the most cost-effective acquisition opportunity. ${ }^{7}$

Overall, the journals of commercial publishers have a far lower median cost than those acquired through scholarly societies, universities, other nonprofits, or library vendors. In contrast, scholarly society journals cost considerably more than any other type. The results are more nuanced, however, if we consider single-journal subscriptions and full-text databases separately. As Table 4 shows, commercial publishers and scholarly societies charge equally high prices for single-journal subscriptions-more than twice the amounts charged by university presses and other nonprofits. This may account for the perception that commercial publishers' journals are expensive, and for the published studies that have supported that assertion based on the list prices of single-journal subscriptions (Table 2). However, a very different pattern emerges when we consider just the journals acquired through full-text databases. For those journals, commercial publishers offer the lowest prices of the five resource provider types. In terms of median cost, the other providers' journals cost at least three times as much, and those in the other nonprofit category cost more than four times as much.

There are clear differences among the seven broad subject areas, with relatively high prices in engineering and the physical sciences but relatively low prices in education and the social sciences (Table 4). These relationships are consistent with those reported in earlier research (Bosch et al., 2020; Dewatripont et al., 2006, 2007; Meyer, 2001; Moghaddam, 2006; Ortelbach et al., 2008; Petersen, 1989, 1990; Rose-Wiles, 2011; White $\&$ Creaser, 2007). Moreover, data for every combination of resource provider and subject area (Table 5) reveal that the lower prices charged by commercial publishers-and the high prices charged by scholarly societies - do not result from differences in the publishers' subject profiles. For instance, commercial publishers have the lowest average prices not just overall, but within most of the six subject areas.

\footnotetext{
7 The Manhattan College serials review incorporated a similar analysis (Walters and Markgren 2020). An iterative selection procedure was used to identify the lowest-cost wanted journals based on a comparison of all 9017 acquisition opportunities-OA journals, single-journal subscriptions, and full-text databases. Each round resulted in the selection of a single database, two databases with the same cost, or all the singlejournal subscriptions that cost less than the next lowest-cost database, based on cost per wanted journal. The lowest-cost acquisition opportunity was selected in the first round. After removing the wanted journals selected in the first round from the list of still-wanted journals, the research team recalculated cost per wanted journal (to account for the reduction in the number of still-wanted journals within some databases) and selected the next lowest-cost journal(s) in the second round, and so on. The process continued for 43 rounds, until the available funds were exhausted. In 43 rounds, the team selected 166 OA journals, 293 single-journal subscriptions, and 21 full-text databases that together provide access to $75 \%$ of the 2717 wanted journals. Among the journals selected in an attempt to acquire the greatest number of wanted titles at the lowest possible cost, the average cost per wanted journal was $\$ 0$ for the OA journals, $\$ 230$ for the singlejournal subscriptions, and $\$ 119$ for the wanted journals acquired through full-text databases.
} 


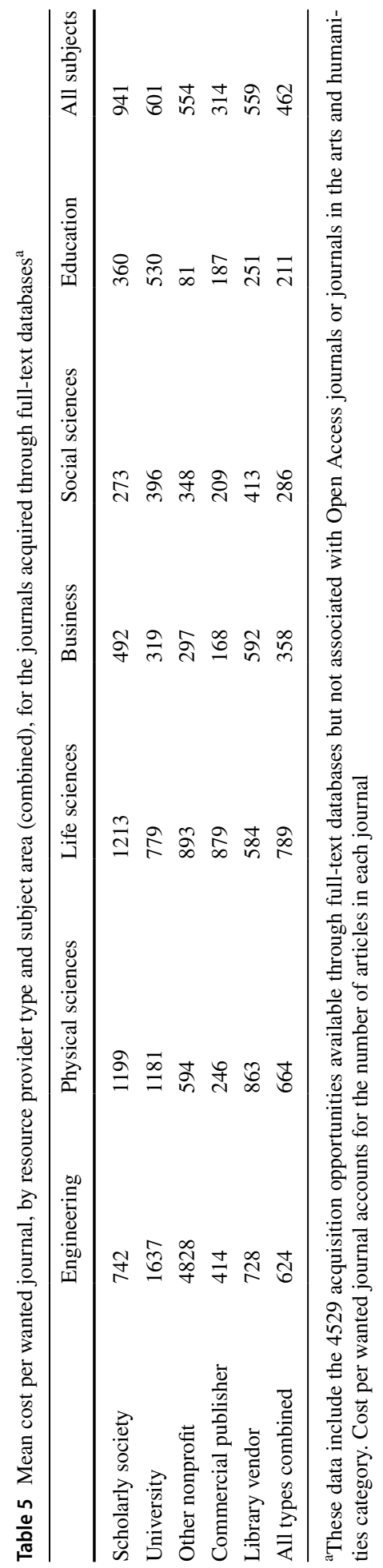


Table 6 Percentage of acquisition opportunities in each subject area, by resource provider type, for the journals acquired through full-text databases ${ }^{\mathrm{a}}$

\begin{tabular}{|c|c|c|c|c|c|c|c|}
\hline & Engineering & $\begin{array}{l}\text { Physical } \\
\text { sciences }\end{array}$ & Life sciences & Business & $\begin{array}{l}\text { Social sci- } \\
\text { ences }\end{array}$ & Education & All subjects \\
\hline $\begin{array}{c}\text { Scholarly } \\
\text { society }\end{array}$ & 36 & 42 & 2 & 13 & 5 & 1 & 100 \\
\hline University & 1 & 13 & 24 & 23 & 34 & 5 & 100 \\
\hline $\begin{array}{l}\text { Other non- } \\
\text { profit }\end{array}$ & 1 & 23 & 18 & 10 & 45 & 4 & 100 \\
\hline $\begin{array}{l}\text { Commercial } \\
\text { publisher }\end{array}$ & 8 & 15 & 13 & 16 & 37 & 11 & 100 \\
\hline $\begin{array}{l}\text { Library } \\
\text { vendor }\end{array}$ & 7 & 13 & 13 & 23 & 38 & 7 & 100 \\
\hline $\begin{array}{l}\text { All types } \\
\text { combined }\end{array}$ & 10 & 17 & 12 & 17 & 34 & 9 & 100 \\
\hline
\end{tabular}

${ }^{a}$ These data include the 4529 acquisition opportunities available through full-text databases but not associated with Open Access journals or journals in the arts and humanities category. The sum of the subject area counts is 5028 rather than 4529 , however, because some journals were included in more than one subject area (e.g., selected by Manhattan College departments in both engineering and the physical sciences)

\section{Within-group variation in cost per wanted journal}

As Table 4 shows, the standard deviation of cost per wanted journal is consistently high, both overall and for most journal types. In other words, there is considerable variation in journal prices within each of the categories (e.g., within the set of commercial publishers' journals or within the set of life science journals). This suggests that the three characteristics shown in the table - acquisition mechanism, resource provider type, and subject areacan explain relatively little of the overall variation in journal prices.

Moreover, the journal categories with especially high standard deviations tend to have strongly right-skewed price distributions and high mean-to-median ratios. That is, they include many lower-cost journals along with a small number of very high-cost journals. Although this pattern can be seen for every type of resource provider, it is most pronounced for the commercial publishers, which account for $55 \%$ of the 5905 acquisition opportunities but for $75 \%$ of the 20 acquisition opportunities with the highest cost per wanted journal. The very high prices of commercial publishers' most expensive journals may obscure the fact that these same publishers offer relatively low prices, overall.

\section{Systematic variation in the explanatory variables}

Information about the journals acquired through each type of resource provider may help explain why their prices differ. As Table 6 shows, the scholarly societies account for relatively many wanted journals in engineering and the physical sciences but for relatively few in the life sciences, the social sciences, and education. This can be attributed chiefly to four societies with very extensive publishing activities: IEEE, the American Chemical Society, the Royal Society of Chemistry, and the Institute of Physics. In contrast, university presses and other nonprofits account for relatively many journals in the life sciences but for relatively few in engineering. Commercial publishers and 
Table 7 Mean values of selected covariates, by resource provider type and subject area (combined), for the journals acquired through full-text databases ${ }^{\mathrm{a}}$

Engineering Physical Life sciences Business Social sci- Education All subjects
sciences ences

\begin{tabular}{|c|c|c|c|c|c|c|c|}
\hline \multicolumn{8}{|c|}{ Publisher size } \\
\hline $\begin{array}{c}\text { Scholarly } \\
\text { society }\end{array}$ & 151 & 86 & 14 & 153 & 32 & 33 & 106 \\
\hline University & 127 & 116 & 123 & 116 & 100 & 108 & 114 \\
\hline $\begin{array}{l}\text { Other non- } \\
\text { profit }\end{array}$ & 6 & 46 & 60 & 27 & 50 & 24 & 47 \\
\hline $\begin{array}{c}\text { Commercial } \\
\text { publisher }\end{array}$ & 525 & 462 & 435 & 534 & 556 & 598 & 526 \\
\hline $\begin{array}{l}\text { Library } \\
\text { vendor }\end{array}$ & 130 & 166 & 65 & 276 & 127 & 333 & 169 \\
\hline $\begin{array}{l}\text { All types } \\
\text { combined }\end{array}$ & 303 & 277 & 273 & 378 & 376 & 512 & 353 \\
\hline \multicolumn{8}{|c|}{ JIF percentile } \\
\hline $\begin{array}{c}\text { Scholarly } \\
\text { society }\end{array}$ & 78 & 78 & 74 & 76 & 58 & 68 & 75 \\
\hline University & 47 & 66 & 66 & 75 & 63 & 46 & 66 \\
\hline $\begin{array}{l}\text { Other non- } \\
\text { profit }\end{array}$ & 43 & 94 & 60 & 80 & 64 & 11 & 69 \\
\hline $\begin{array}{c}\text { Commercial } \\
\text { publisher }\end{array}$ & 60 & 62 & 62 & 60 & 59 & 64 & 60 \\
\hline $\begin{array}{l}\text { Library } \\
\text { vendor }\end{array}$ & 35 & 43 & 34 & 64 & 58 & 33 & 52 \\
\hline $\begin{array}{l}\text { All types } \\
\text { combined }\end{array}$ & 62 & 63 & 54 & 64 & 59 & 56 & 60 \\
\hline \multicolumn{8}{|l|}{ Journal size } \\
\hline $\begin{array}{c}\text { Scholarly } \\
\text { society }\end{array}$ & 446 & 664 & 233 & 152 & 62 & 85 & 499 \\
\hline University & 368 & 374 & 175 & 47 & 52 & 56 & 130 \\
\hline $\begin{array}{l}\text { Other non- } \\
\text { profit }\end{array}$ & 131 & 24 & 56 & 20 & 39 & 18 & 37 \\
\hline $\begin{array}{l}\text { Commercial } \\
\text { publisher }\end{array}$ & 405 & 329 & 152 & 84 & 65 & 69 & 141 \\
\hline $\begin{array}{l}\text { Library } \\
\text { vendor }\end{array}$ & 153 & 230 & 89 & 71 & 51 & 34 & 92 \\
\hline $\begin{array}{l}\text { All types } \\
\text { combined }\end{array}$ & 373 & 386 & 133 & 82 & 59 & 60 & 157 \\
\hline
\end{tabular}

${ }^{a}$ These data include the 4529 acquisition opportunities available through full-text databases but not associated with Open Access journals or journals in the arts and humanities category

library vendors do not diverge greatly from the overall pattern in their subject output, not least because they define that pattern; together, they account for $77 \%$ of the acquisition opportunities.

Publisher size is strongly associated with resource provider type, and the main relationship is readily apparent; the commercial publishers are far larger than the others (Table 7). While the variations in publisher size by subject area are comparatively minor, the 
databases of the larger scholarly societies (in terms of publishing activity) tend to include relatively many engineering and business journals. Likewise, the databases of the larger library vendors tend to include many business and education journals.

Table 7 also presents average JIF percentile values by resource provider type and subject area. In general, the journals acquired through library vendors' databases tend to have relatively low citation impact. This is not surprising, since many vendors' databases are tailored to the needs of undergraduates, whose criteria for relevance are likely to be different from those of faculty and graduate students (Hulseberg \& Twait, 2016; Taylor, 2013). Likewise, wanted journals in education and the life sciences tend to have lower JIF percentile scores than those in the other fields. (Each percentile score represents the journals' impact relative to the other journals in the same subject area.) A review of the wanted journals selected by Manhattan College faculty in education and the life sciences suggests that many were chosen for their potential influence on teaching and practice rather than their research impact.

Finally, Table 7 presents summary data for journal size-the number of articles per journal in 2019. Wanted journals in engineering and the physical sciences typically publish far more articles per year than those in education, business, and the social sciences. The journals of the scholarly societies also tend to be large, at least partly due to their subject emphases. In contrast, the journals in the other nonprofit category publish an average of just 37 articles per year.

\section{Regression results and discussion}

As noted in the Methods section, all four regressions are limited to the journals acquired through full-text databases. Regression Model 1 includes journals from both commercial and nonprofit providers but uses only a limited set of independent variables, representing resource provider type and subject area. In contrast, Model 2 incorporates the full set of explanatory variables: resource provider type, subject area, publisher size, JIF percentile, and journal size. Consequently, the differences between the regression coefficients for Model 1 and Model 2 may help reveal whether the apparent impact of resource provider type can actually be attributed to other characteristics - publisher size, in particular. The results for publisher size may therefore help us understand whether larger publishers can charge higher prices due to increased market share and reduced competition, as argued by McCabe (2000, 2001, 2002), or whether they are able to charge lower prices (due to global economies of scale, perhaps) when faced with incentives to do so-through the competition that arises when teaching-oriented colleges and universities consider cost, among other factors, in their selection decisions. The second possibility, if supported, would suggest that particular journals and databases may sometimes be regarded as substitutes despite their unique content.

\section{Model 1}

Table 8 presents the results of the main regression analyses. Model 1 includes explanatory variables representing just resource provider type and subject area. Because the dependent variable, cost per wanted journal, was entered in natural log form, the B coefficients cannot be interpreted as dollar amounts. They have therefore been converted into effect coefficients, which show the percentage change in cost per wanted journal associated with 
Table 8 Regression results for the journals acquired through full-text databases ${ }^{\mathrm{a}}$

\begin{tabular}{|c|c|c|c|c|c|c|c|c|}
\hline & \multicolumn{4}{|l|}{ Model 1} & \multicolumn{4}{|l|}{ Model 2} \\
\hline & Effect $(\%)^{\mathrm{b}}$ & B & SE & Beta & Effect $(\%)^{\mathrm{b}}$ & $\mathrm{B}$ & SE & Beta \\
\hline \multicolumn{9}{|l|}{ Resource provider type } \\
\hline Scholarly society & 161 & $0.960 *$ & 0.090 & 0.170 & 169 & $0.990 *$ & 0.101 & 0.176 \\
\hline University & 220 & $1.164 *$ & 0.112 & 0.148 & 331 & $1.462 *$ & 0.117 & 0.186 \\
\hline Other nonprofit & 227 & $1.185^{*}$ & 0.139 & 0.120 & 439 & $1.685^{*}$ & 0.144 & 0.171 \\
\hline Commercial publisher & - & - & - & - & - & - & - & - \\
\hline Library vendor & 186 & $1.052 *$ & 0.053 & 0.290 & 303 & $1.395^{*}$ & 0.066 & 0.385 \\
\hline \multicolumn{9}{|l|}{ Subject area } \\
\hline Engineering & 51 & $0.410 *$ & 0.080 & 0.079 & 23 & $0.204 *$ & 0.077 & 0.039 \\
\hline Physical sciences & 15 & $0.140 *$ & 0.062 & 0.034 & -12 & $-0.127 *$ & 0.062 & -0.031 \\
\hline Life sciences & 57 & $0.451 *$ & 0.069 & 0.095 & 66 & $0.507^{*}$ & 0.067 & 0.107 \\
\hline Business & -3 & -0.028 & 0.062 & -0.007 & -2 & -0.020 & 0.059 & -0.005 \\
\hline Social sciences & - & - & - & - & - & - & - & - \\
\hline Education & -1 & -0.013 & 0.082 & -0.002 & -4 & -0.044 & 0.079 & -0.008 \\
\hline Publisher size & & & & & 0.080 & $0.0008 *$ & 0.0001 & 0.130 \\
\hline JIF percentile & & & & & 0.150 & 0.0015 & 0.0008 & 0.026 \\
\hline Journal size & & & & & 0.130 & $0.0013^{*}$ & 0.0001 & 0.284 \\
\hline Y-intercept & & 4.481 & 0.041 & & & 3.856 & 0.085 & \\
\hline Adjusted $\mathrm{R}^{2}$ & & 0.12 & & & & 0.20 & & \\
\hline Std. error of estimate & 363 & 1.532 & & & 332 & 1.463 & & \\
\hline$n$ & & & 4529 & & & & 4529 & \\
\hline
\end{tabular}

${ }^{\text {a }}$ The dependent variable, cost per wanted journal, was calculated with the new method, which accounts for the number of articles in each journal. It was entered into the regression in natural log form. Beta is the standardized regression coefficient. Commercial publisher and social sciences are the reference categories

${ }^{b}$ Percentage change in cost per wanted journal associated with a one-unit change in the independent variable, or with inclusion in the indicated category. Effect is equal to $(\exp (\mathrm{B})-1) * 100$

${ }^{*}$ Significant at the 0.05 level (two-tailed). Because these data include the entire population-all the acquisition opportunities available through full-text databases but not associated with Open Access journals or journals in the arts and humanities category-this designation simply indicates that the regression coefficient is high relative to the standard error

a one-unit change in the independent variable-or, for categorical variables, the percentage change associated with inclusion in the indicated category. Each effect coefficient is equal to $(\exp (\mathrm{B})-1) * 100$.

As might be expected with so few covariates, the Model 1 effect coefficients for resource provider type (Table 8) are closely related to the median cost values for the journals in fulltext databases (Table 4, new calculation method); $r=0.97$. Among the journals acquired through full-text databases, cost per wanted journal is substantially higher for nonprofits than for commercial publishers, even when controlling for subject area. As the Model 1 effect coefficients show, the "added cost" of acquiring a journal through a database provider other than a commercial publisher ranges from $161 \%$ (scholarly society) to $227 \%$ (other nonprofit).

Model 1 also confirms that subject area has an independent impact on cost per wanted journal. The regression coefficients for the various subject areas are not entirely consistent with the Table 4 results, however. Although journals in engineering and the physical 
sciences have the highest mean and median prices, the regression coefficient for the life sciences is higher than that for any other subject. Two factors may account for this. First, the subject area prices shown in Table 4 refer to all acquisition opportunities while the regression results include only those journals acquired through full-text databases. As Table 5 shows, the life sciences do have the highest average cost when only the journals acquired through full-text databases are considered. Second, the life science cost differential (i.e., the average cost of a life science journal relative to the average for all subject areas) is much greater for commercial publishers than for any other resource provider type. (Again, see Table 5.) The high regression coefficient for the life sciences therefore offsets the cost-reducing effect of commercial publisher status.

Because Model 1 includes only those explanatory variables shown in Table 4, the regression results demonstrate that the main findings of the descriptive analyses remain valid when resource provider type and subject area are considered jointly. At the same time, the results also reveal that the Model 1 covariates are weak predictors of cost per wanted journal. (See the $\mathrm{R}^{2}$ and standard error of estimate values in Table 8.) Although the Model 1 predictors do have a substantial influence on cost, there is still much unexplained variation in prices among the journals within each resource provider group or subject group.

\section{Model 2}

Model 2 (Table 8) adds three more explanatory variables: publisher size, JIF percentile (citation impact per article), and journal size (articles per year). While we might expect that the addition of these covariates would reduce the apparent impact of resource provider type, all four provider type coefficients are higher in Model 2 than in Model 1. That is, resource providers other than commercial publishers tend to have secondary characteristics-publisher size, JIF percentile, and/or journal size - that are associated with low prices, and the higher coefficients for resource provider type in Model 2 offset those effects. Conversely, commercial publishers tend to have secondary characteristics that are associated with higher prices, and the independent, price-reducing effect of commercial publisher status is even greater when those secondary characteristics are taken into account. In Model 2, the added cost of acquiring a journal through a database provider other than a commercial publisher ranges from $169 \%$ (scholarly society) to $439 \%$ (other nonprofit), and the average of the four effect coefficients is $311 \%$.

The Model 2 subject area results are very similar to the Model 1 results. Again, for the journals acquired through full-text databases, those in the life sciences and engineering cost more, all else equal, than those in business, education, and the social sciences.

As Table 8 shows, publisher size is weakly but directly associated with cost per wanted journal when we consider commercial and nonprofit journals together. Specifically, a 100 -journal increase in publisher size can be expected to bring an $8 \%$ increase in cost. This finding is consistent with McCabe's (2000) conclusion that larger publishers have greater market power and can therefore avoid competition. Overall, however, the impact of publisher size is not nearly as great as the impact of resource provider type; and, as presented later in the discussion of Models 3 and 4, the effect of publisher size varies substantially based on the for-profit/nonprofit status of the resource provider.

Model 2 also introduces JIF percentile, an indicator of relative citation impact per article. The relationship between JIF percentile and cost per wanted journal is very weak, however. All else equal, an increase of one standard deviation (29 points) in JIF percentile is 
associated with a price increase of just $4 \%$. This result does not lend much support to the idea that the journals in greatest demand (i.e., higher-impact journals) can charge higher prices because subscribers are willing to pay more for them. Likewise, it is inconsistent with McCabe's (2000) alternative assertion that higher-demand journals will have relatively low prices because the publishers of those journals can increase revenue more effectively by adding subscribers than by raising prices. ${ }^{8}$

Journal size, the third new variable, has the second-highest impact of all the covariates in Model 2. (See the beta coefficients.) An increase in journal size of one standard deviation (362 articles per year) is associated with a $47 \%$ increase in cost. Although many previous studies have reported similar results, those analyses were based on single-journal subscriptions, for which the interpretation was straightforward: journals that publish more articles cost more to produce and are more valuable to subscribers. ${ }^{9}$ In this case, however, the new method of calculating cost per wanted journal explicitly accounts for journal size. (As explained in the Methods section, the cost of each database was allocated among the database's wanted journals in direct proportion to their article counts.) The high impact of journal size may perhaps be attributed to the cost allocation method itself. The exact specification of the relationship between journal size and cost is not central to this investigation, however, since changes in the allocation of costs among the wanted journals within each database would not alter the average cost per journal for each resource provider type.

As noted earlier, the four resource provider coefficients are all higher in Model 2 than in Model 1. This change cannot be attributed to the addition of JIF percentile, since (a) the various resource providers do not differ much in their average citation impact (Table 7) and (b) JIF percentile has only a minor influence on cost per wanted journal (Table 8). Likewise, the increase cannot be attributed to the journal size variable. Although journal size is directly related to price, commercial publishers' journals are not especially large or small. We can therefore tentatively conclude that the increase in the resource provider coefficients is related to publisher size. Commercial publishers typically publish far more journals than nonprofits, and publisher size is directly related to cost per wanted journal.

Model 2 has a higher $\mathrm{R}^{2}$ value than Model 1 and a slightly lower standard error of estimate. Overall, however, Model 2 is similarly ineffective in explaining variation in cost per wanted journal. It is possible that the main determinants of cost are factors not included in the regressions. The identification and consideration of those determinants might well reduce (or increase) the apparent impact of resource provider type.

\section{Models 3 and 4: results for nonprofit and for-profit resource providers}

Table 9 shows the results of separate regressions that include just for-profit resource providers (Model 3) and nonprofit resource providers (Models 4). Each uses the full set of explanatory variables.

\footnotetext{
8 Two methodological issues may also be relevant. First, the apparent impact of JIF percentile may depend on the method used to allocate total database cost among the wanted journals in each database. Second, JIF percentile may not be the best indicator of demand. Both these issues are discussed in the Conclusion.

9 With just a few exceptions, all the studies shown in Table 2 report a direct relationship between price and one or more indicators of journal size. Chressanthis and Chressanthis (1994a, 1994b) found no relationship, and Dewatripont et al. (2006) did not include a journal size variable.
} 
Table 9 Regression results for the nonprofit and for-profit journals acquired through full-text databases ${ }^{\mathrm{a}}$

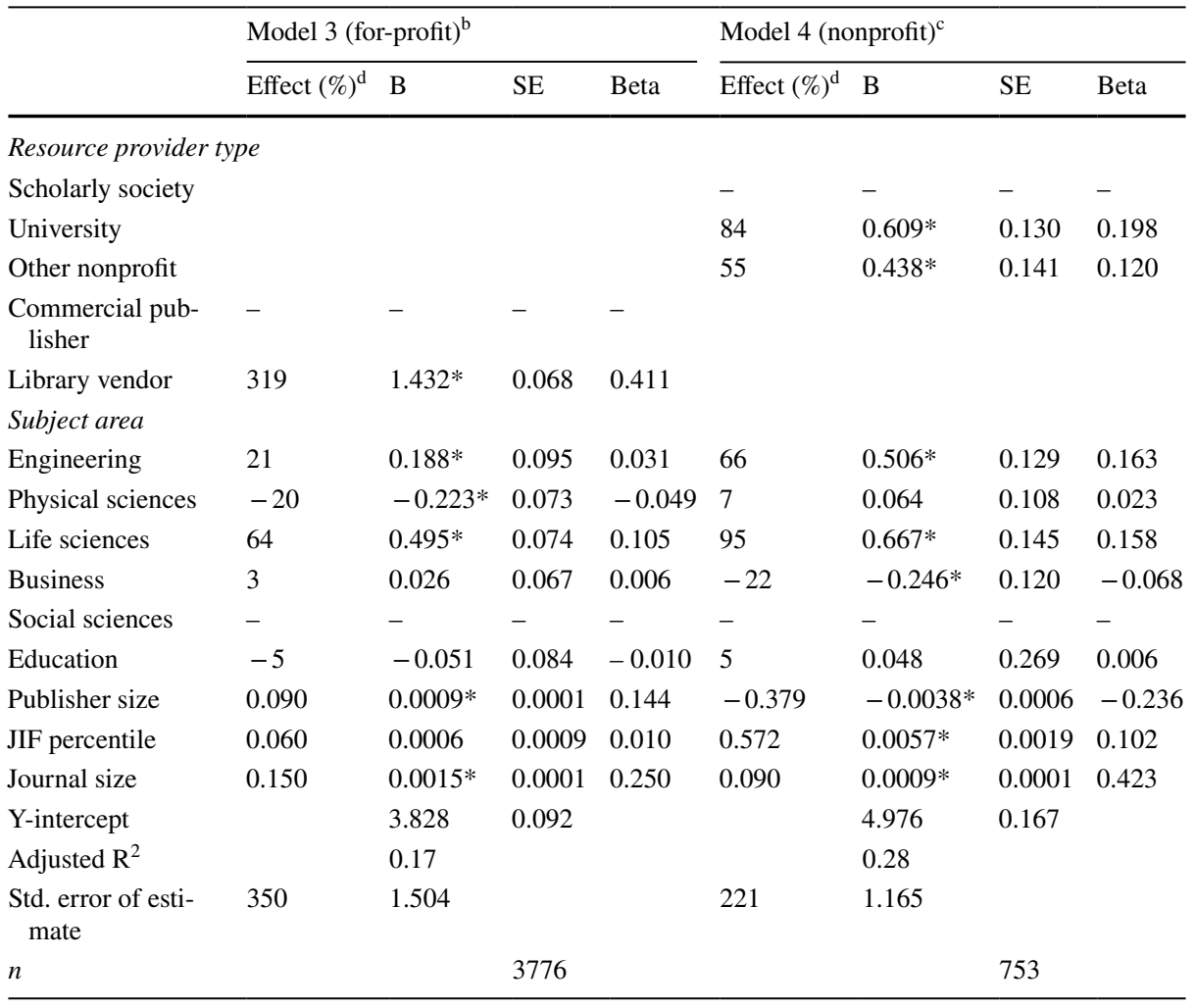

${ }^{\text {a }}$ The dependent variable, cost per wanted journal, was calculated with the new method, which accounts for the number of articles in each journal. It was entered into the regression in natural $\log$ form. Beta is the standardized regression coefficient. Scholarly society, commercial publisher, and social sciences are the reference categories

${ }^{\mathrm{b}}$ This analysis includes the commercial publisher and library vendor resource provider types

${ }^{\mathrm{c}}$ This analysis includes the scholarly society, university, and other nonprofit resource provider types

${ }^{\mathrm{d}}$ Percentage change in cost per wanted journal associated with a one-unit change in the independent variable, or with inclusion in the indicated category. Effect is equal to $(\exp (\mathrm{B})-1) * 100$

${ }^{*}$ Significant at the 0.05 level (two-tailed). Because these data include the entire population, this designation simply indicates that the regression coefficient is high relative to the standard error

The Model 3 results, for the journals (acquisition opportunities) offered by commercial publishers and library vendors, are nearly identical to the Model 2 results shown in Table 8. This is not surprising, since 83\% of the cases included in Model 2 are also included in Model 3.

For nonprofit resource providers (Model 4), many of the regression coefficients are also broadly similar to the Model 2 results. Again, the relatively high cost of scholarly society journals can be attributed at least partly to their subject coverage and size (articles per year) while the high cost of university-sponsored journals and other nonprofit journals is 
more closely linked to resource provider type per se. Likewise, journals in engineering and the life sciences cost more than those in the other subject areas, all else equal.

However, a key difference between for-profit and nonprofit journals can be seen in the results for publisher size (Models 3 and 4). Among the for-profit resource providers, the larger publishers tend to charge slightly higher prices, all else equal. Among the nonprofits, however, the larger publishers tend to charge lower prices; a 100-journal increase in publisher size is associated with a $38 \%$ decrease in cost. Notably, this effect is relatively strong-more than four times as strong as the contrary effect for for-profit providers.

Although the reasons for this relationship are not immediately apparent, the Table 9 results suggest a two-part explanation:

1. The commercial publishers, most of which maintain large journal portfolios, have nearly all learned to take advantage of global economies of scale. They all have strong incentives to reduce their cost of production, along with at least some reason to maintain low prices, at least where master's and bachelor's universities are concerned. (See the literature review.) Because almost every commercial publisher is large, however, the ability to keep prices low does not increase as publisher size increases.

2. The nonprofit publishers are almost all smaller than the commercial publishers. Among nonprofits, it is only the larger organizations that can take full advantage of economies of scale in the same way that commercial publishers do, at least with regard to their full-text databases. Within this group, publisher size is therefore associated with lower cost per wanted journal.

The regression results are consistent with this explanation, although they provide only indirect evidence and cannot be said to support it. As noted in the Conclusion, a more direct evaluation of this possibility may be warranted.

Finally, Table 9 reveals that the direct relationship between JIF percentile and cost per wanted journal is much stronger for nonprofit journals than for for-profit journals. This result is incongruent with McCabe's (2000) assertion that demand and price are inversely related-if we accept impact factor as an indicator of demand. However, it is consistent with the more general principle that consumers will pay more for the "better" journals.

\section{Conclusion}

\section{Key findings}

The empirical results of this study include four key findings. Although these findings are specific to Manhattan College, they are likely to prevail at many other teaching-oriented colleges and universities in the United States. ${ }^{10}$

1. Wanted journals - those identified as important by the faculty - cost less, on average, when acquired through full-text databases rather than as single-journal subscriptions.

10 A later section discusses the extent to which these results can be generalized to other institutions. 
2. In general, the journals acquired through commercial publishers' databases cost less than those acquired through the databases of scholarly societies, universities, other nonprofits, and library vendors.

3. The lower prices of commercial publishers' journals cannot be readily attributed to subject area, publisher size, citation impact, or journal size. In fact, the independent, price-reducing effect of commercial publisher status increases when other variables are taken into account.

4. Publisher size is directly but weakly associated with cost per wanted journal within the set of for-profit journals. However, publisher size is inversely and more strongly associated with cost per wanted journal within the set of nonprofit journals.

The first two findings confirm the results of earlier investigations (Bergstrom et al., 2014; Walters \& Markgren, 2021). Moreover, the price differentials reported by Walters and Markgren are not appreciably altered when revised prices are used or when cost per wanted journal is recalculated to account for the size of each journal.

\section{Journal prices, publisher size, and price discrimination}

As shown in previous research, the larger commercial publishers tend to charge higher prices where single-journal subscriptions are concerned (Coomes et al., 2017; McCabe, 2001, 2002; Ortelbach et al., 2008). However, this study presents a second possibility that is specific to the journals acquired through online databases - that the larger publishers are both willing and able to lower their prices for master's and undergraduate institutions. This idea is based on three principles:

1. Resource providers have an incentive to practice price discrimination (i.e., charge lower prices) when dealing with colleges and universities that are willing to cancel subscriptions if they feel that the prices are too high. While authors such as Björk (2021) and Plasmeijer (2002) have assumed that the library's goal is to provide access to every wanted article, many bachelor's and master's institutions have a different goal: to provide access to an adequate number of good journals - or, more precisely, good articles - in a cost-effective way. As discussed more fully in the literature review, particular journals and databases may provide unique content, but they seldom provide unique opportunities to build collections that includes a sufficient number of high-quality journals.

2. In comparison with print journals, online journals - and especially those included in full-text databases - have a relatively high fixed cost (the expenditure needed to produce the journal regardless of the number of subscribers) and a low marginal cost (the expenditure needed to provide access to one more subscriber once the fixed cost has been paid) (Bergstrom et al., 2014; Haank, 2001; Larivière et al., 2015). This gives the larger publishers an additional advantage. If a library questions the price of a particular bundle of journals, publishers with large journal portfolios can easily add more journals to sweeten the deal. They can also provide value-added features that are less often supported by the smaller publishers, such as bibliographic databases that are large enough to be useful for purposes of document discovery-i.e., databases with enough potentially relevant papers to make searching them worthwhile. 
3. The online environment has improved the potential for reducing production costs through large-scale standardization, outsourcing, relocation of operations, and innovation. The larger publishers are better positioned to take advantage of this.

This explanation suggests that if commercial publishers can charge lower prices because they are larger, nonprofits and library vendors might also be able to reduce the prices of their full-text databases by publishing more journals.

The regression results for all journals (Table 8) and commercially published journals (Table 9) do not support this explanation. In fact, they show a weak but direct relationship between publisher size and cost per wanted journal. On the other hand, the results for nonprofit resource providers (Table 9) reveal a moderately strong, inverse relationship between publisher size and cost per wanted journal. This leaves open the possibility that nearly all commercial publishers, but just the larger nonprofits, can reduce their database prices by taking full advantage of price discrimination and global economies of scale. After all, most commercial publishers are large by nonprofit standards, but only five nonprofits publish more than 45 of the nearly 3000 wanted journals selected by Manhattan College faculty. The explanation set forth here is conjectural, but it may be worthy of further investigation.

\section{Limitations of the study}

Unfortunately, there is no reliable way of knowing how to best allocate the price of a fulltext database among the wanted journals in the database. The regression coefficients for JIF percentile and journal size must be interpreted in light of this fact. For instance, the allocation method used here (Tables 4-9) accounts for journal size but not for citation impact. The measured relationship between cost and JIF percentile therefore reflects just (a) the average citation impact of all the resource provider's journals and (b) the extent to which citation impact is associated with journal size (since journal size was considered in the allocation of database costs). Intuitively, this method-allocating cost in proportion to journal size - seems preferable to the earlier method of assuming that each wanted journal in a particular database is of equal value. Nonetheless, other methods, such as allocating database cost in proportion to citation impact or specifying a non-proportional relationship between cost and journal size, might have led to different results. ${ }^{11}$

It is also important to realize that while citation impact (IF percentile) was used here to represent the demand for particular journals, its use for that purpose is not well established. Although studies of single-journal subscriptions have generally used total circulation or library circulation to represent demand (Bensman, 1996; Chressanthis \& Chressanthis, 1994a, 1994b; Ortelbach et al., 2008; Petersen, 1992), there is no obvious way to gauge the demand for particular journals that are acquired through full-text databases, since most databases include important, high-demand journals as well as others for which there is little demand. Data availability is also a problem. The standard sources of journal circulation

\footnotetext{
11 In practice, this may not be a major issue, for two reasons. First, although changes in the allocation method have the potential to influence the median cost as well as the apparent impact of the explanatory variables, they cannot alter the mean cost per article for each resource provider type (for the journals acquired through full-text databases). Second, further analyses suggest that the substantive results for resource provider type, subject area, and publisher size do not change appreciably, overall or for nonprofit resource providers, when journal size is replaced with citations per journal in the calculation of cost per wanted journal.
} 
data do not account for access through full-text databases (ProQuest, 2021), and the library holdings information in WorldCat is sometimes incomplete or biased (Carlstone, 2017; van Ballegooie, 2016).

Because the wanted journal list and the price data used in this investigation are specific to Manhattan College, it is reasonable to wonder whether the results can be generalized to other master's universities. Fortunately, there are several reasons why generalizations may be warranted. Manhattan College is typical of many institutions in its size, mission, reputation, selectivity, student characteristics, teaching/research focus, and library budget. The curriculum is not unusual except for an emphasis on engineering, which accounts for $30 \%$ of enrolled undergraduates, and the faculty's journal selections include most of the high-impact journals in fields typically taught at U.S. undergraduate colleges (Walters \& Markgren, 2019). Moreover, more than half the library's journal/database budget is spent on resources acquired through WALDO and LYRASIS, two of the largest library consortia in the United States. The license terms for many online resources, including our largest journal databases, were therefore negotiated by WALDO and LYRASIS rather than the College, and the same consortial price schedules apply to the other member libraries ( 945 and 905 institutions, respectively). The library has not systematically or actively negotiated prices in recent years, although ad hoc negotiations (e.g., "that price seems high for the number of students we have in those subject areas") have occasionally been pursued. Moreover, our negotiating practices are in no way unusual, and it is likely that individually negotiated prices are less common at master's institutions than at the major research universities.

\section{Further research}

Three suggestions for further research emerge directly from the methods used here and in previous investigations. First, researchers may find it helpful to consider alternative criteria and procedures for allocating database costs among the journals in each database. This might lead to the identification of consistent relationships and, ideally, to the development of guidelines regarding the best approach. Second, more analyses should consider for-profit and nonprofit journals separately in order to clarify the ways in which they differ. Only two previous studies have considered these distinctions (Bensman, 1996; Ortelbach et al., 2008). Finally, analyses that focus on market power should be limited to a single field (a single market) and should express publisher size in terms of market share. Of the studies shown in Table 2, only Coomes et al. (2017) meets this criterion.

Four broader questions might also help establish a stronger foundation for further research. First, we can ask whether it is realistic to focus on title-by-title competition and uniqueness of content when most journals are acquired through full-text databases. As noted earlier, librarians at institutions other than the major research universities may work toward the goal of building a sufficiently large collection of good journals rather than trying to provide immediate access to every wanted journal. This goal was explicitly incorporated into a recent large-scale serials review, and it appears to underpin many of the selection decisions made by academic librarians (Walters \& Markgren, 2020).

Second, we can ask whether librarians identify a set of wanted journals, formally or informally, and acquire the databases that provide cost-effective access to an adequate number of them, or whether they consider each database as a unified whole without focusing on the particular journals included within each one. The second approach may be more common at libraries without designated subject specialists, or among librarians who are 
accustomed to comparing purely bibliographic databases on that basis (e.g., Sociological Abstracts versus SocINDEX, or ABI/INFORM versus Business Source Complete). We should recognize that full-text databases may be regarded as substitutes even if the journals within them are not, and that the objective assessment of journal content may be less important than the perceptions of the individuals who make the selection decisions. In most cases, these individuals are librarians, and their perceptions may ultimately be more important, in economic terms, than the perceptions of faculty, students, and other end users.

Third, we should consider whether the profit-increasing effect of publisher mergers can be attributed to factors other than reduced competition, since similar empirical results might arise due to other changes associated with these mergers. In particular, the new owners may replace passive management of the journal portfolio with a more active approach, aggressively adding journals in emerging research areas and selling or discontinuing less profitable titles. Mergers might also spur many of the changes associated with economies of scale, such as standardization of production processes, relocation, and outsourcingchanges that can lead to both lower production costs (higher profits) and lower prices for subscribers.

Finally, extreme price discrimination appears to be an effective strategy for the major commercial publishers, since nearly all of them have adopted this practice (Bergstrom et al., 2014). The key research question is therefore not why commercial publishers engage in price discrimination, but why some nonprofits do not. As noted earlier, it may be that only the larger nonprofit organizations have the resources needed to evaluate their own pricing strategies in a systematic way and to negotiate complex or flexible license terms that allow them to take full advantage of price discrimination. If this is indeed the case, it supports the argument that each nonprofit can benefit from economies of scale by publishing and managing a greater number of journals.

Acknowledgements I am grateful for the advice and assistance of Susanne Markgren, Geoffrey Shideler, Esther Isabelle Wilder, Brendon Ford, Helen White, the Manhattan College faculty, and the organizations that provided price information.

Funding None.

Data availability Although the raw data include confidential price information, the author will be glad to provide additional summary data on request.

\section{Declarations}

Conflicts of interest The author declares that he has no conflict of interest.

Open Access This article is licensed under a Creative Commons Attribution 4.0 International License, which permits use, sharing, adaptation, distribution and reproduction in any medium or format, as long as you give appropriate credit to the original author(s) and the source, provide a link to the Creative Commons licence, and indicate if changes were made. The images or other third party material in this article are included in the article's Creative Commons licence, unless indicated otherwise in a credit line to the material. If material is not included in the article's Creative Commons licence and your intended use is not permitted by statutory regulation or exceeds the permitted use, you will need to obtain permission directly from the copyright holder. To view a copy of this licence, visit http://creativecommons.org/licenses/by/4.0/. 


\section{References}

Australian Research Council. (2010). Archived documents: ERA 2010. Canberra: Australian Research Council. https://www.arc.gov.au/excellence-research-australia/archived-era-documents.

Bensman, S. J. (1996). The structure of the library market for scientific journals: the case of chemistry. Library Resources \& Technical Services, 40(2), 145-170.

Bergstrom, T. C. (2001). Free labor for costly journals? Journal of Economic Perspectives, 15(3), $183-198$.

Bergstrom, T. C., Courant, P. N., McAfee, R. P., \& Williams, M. A. (2014). Evaluating big deal journal bundles. Proceedings of the National Academy of Sciences, 111(26), 9425-9430.

Björk, B. C. (2021). Why is access to the scholarly journal literature so expensive? Portal: Libraries and the Academy, 21(2), 177-192.

Bosch, S., Albee, B., \& Romaine, S. (2020, April 14). Costs outstrip library budgets: Periodicals price survey, 2020. Library Journal. https://www.libraryjournal.com/?detailStory=Costs-Outstrip-Libra ry-Budgets-Periodicals-Price-Survey-2020.

Carlstone, J. (2017). Scoring the quality of e-serials MARC records using Java. Serials Review, 43(3-4), 271-277.

Chressanthis, G. A., \& Chressanthis, J. D. (1994a). The determinants of library subscription prices of the top-ranked economics journals: an econometric analysis. Journal of Economic Education, 25(4), 367-382.

Chressanthis, G. A., \& Chressanthis, J. D. (1994b). A general econometric model of the determinants of library subscription prices of scholarly journals: the role of exchange rate risk and other factors. Library Quarterly, 64(3), 270-293.

Christensen, J. O. (1993). Do we know what we are paying for? A comparison of journal subscription costs. Serials Review, 19(2), 39-61.

Clarivate Analytics. (2018). Journal citation reports. Philadelphia, PA: Clarivate Analytics.

Coomes, O. T., Moore, T. R., \& Breau, S. (2017). The price of journals in geography. The Professional Geographer, 69(2), 251-262.

Cornell University. (1998). Journal price study: Core agricultural and biological journals. Ithaca, NY: Cornell University. https://hdl.handle.net/1813/41479.

Davis, P. M. (2002). Where to spend our e-journal money? Defining a university library's core collection through citation analysis. Portal Libraries and the Academy, 2(1), 155-166.

Dewatripont, M., Ginsburgh, V., Legros, P., \& Walckiers, A. (2007). Pricing of scientific journals and market power. Journal of the European Economic Association, 5(2-3), 400-410.

Dewatripont, M., Ginsburgh, V., Legros, P., Walckiers, A., Devroey, J. P., Dujardin, M., Vandooren, F., Dubois, P., Foncel, J., Ivaldi, M., \& Heusse, M. D. (2006). Entry, prices, costs and quality. In Study on the economic and technical evolution of the scientific publication markets in Europe (pp. 27-41). Brussels, Belgium: European Commission. https://dipot.ulb.ac.be/dspace/bitstream/ 2013/9545/1/md-0005.pdf.

Graham, L. J. (2008). Rank and file: assessing research quality in Australia. Educational Philosophy and Theory, 40(7), 811-815.

Haank, D. (2001). Is electronic publishing being used in the best interests of science? The publisher's view. In Proceedings of the Second ICSU/UNESCO International Conference on Electronic Publishing in Science held in association with CODATA, IFLA and ICSTI at UNESCO House, Paris, 20-23 February 2001. http://eos.wdcb.ru/eps2/eps02008/eps02008.pdf

Hulseberg, A., \& Twait, M. (2016). Sophomores speaking: an exploratory study of student research practices. College \& Undergraduate Libraries, 23(2), 130-150.

Johnson, R., \& Fosci, M. (2015). On shifting sands: assessing the financial sustainability of UK learned societies. Learned Publishing, 28(4), 274-281.

Johnson, R., Watkinson, A., \& Mabe, M. (2018). The STM report: An overview of scientific and scholarly publishing. Fifth edition. The Hague, The Netherlands: STM: International Association of Scientific, Technical, and Medical Publishers. https://www.stm-assoc.org/2018_10_04_STM_Report_ 2018.pdf.

Lamp, J. (2010). ERA 2010 finalised lists: 2010 comprehensive final lists. Melbourne, Australia: Deakin University. http://lamp.infosys.deakin.edu.au/era/?page=jmain.

Larivière, V., Haustein, S., \& Mongeon, P. (2015). The oligopoly of academic publishers in the digital era. PLOS ONE, 10(6), e0127502.

Liu, L. G. (2005). Factors determining subscription prices of scholarly journals in business discipline: themes and variations. Library Collections, Acquisitions, \& Technical Services, 29(4), 382-394.

Liu, L. G. (2011). Economics of scholarly publishing: exploring the causes of subscription price variations of scholarly journals in business subject-specific areas. Library Quarterly, 81(2), 211-232. 
Liu, L. G., \& Gee, H. (2017). Determining whether commercial publishers overcharge libraries for scholarly journals in the fields of science, technology, and medicine, with a semilogarithmic econometric model. Library Quarterly, 87(2), 150-172.

McCabe, M. J. (2000). Academic journal pricing and market power: a portfolio approach. Working Paper, School of Economics, Georgia Institute of Technology. https://citeseerx.ist.psu.edu/viewdoc/ summary?doi=10.1.1.138.5225.

McCabe, M. J. (2001). The impact of publisher mergers on journal prices: theory and evidence. The Serials Librarian, 40(1-2), 157-166.

McCabe, M. J. (2002). Journal pricing and mergers: a portfolio approach. American Economic Review, 92(1), 259-269.

McCabe, M. J. (2013). Online access and the scientific journal market: an economist's perspective. Washington, DC: National Academy of Sciences. http://sites.nationalacademies.org/PGA/step/ PGA_063400.

Meyer, R. W. (2001). A tool to assess journal price discrimination. College \& Research Libraries, 62(3), 269-288.

Moghaddam, G. G. (2006). Price and value of electronic journals: a survey at the Indian Institute of Science. Libri, 56(2), 108-116.

Mongeon, P., Siler, K., Archambault, A., Sugimoto, C. R., \& Larivière, V. (2021). Collection development in the era of big deals. College \& Research Libraries, 82(2), 219-236.

Morris, S. (2005). The true costs of scholarly journal publishing. Learned Publishing, 18(2), 115-126.

Murphy, S. A. (2008). The effects of portfolio purchasing on scientific subject collections. College \& Research Libraries, 69(4), 332-340.

Nabe, J., \& Fowler, D. C. (2015). Leaving the "big deal"...five years later. The Serials Librarian, 69(1), 20-28.

National Center for Education Statistics. (2021). IPEDS integrated postsecondary education data system: Compare institutions. Washington, DC: NCES. https://nces.ed.gov/ipeds/use-the-data.

Ortelbach, B., Schulz, S., \& Hagenhoff, S. (2008). Journal prices revisited: A regression analysis of prices in the scholarly journal market. Serials Review, 34(3), 190-198.

Petersen, H. C. (1989). Variations in journal prices: a statistical analysis. The Serials Librarian, 17(1-2), $1-9$.

Petersen, H. C. (1990). University libraries and pricing practices by publishers of scholarly journals. Research in Higher Education, 31(4), 307-314.

Petersen, H. C. (1992). The economics of economics journals: a statistical analysis of pricing practices by publishers. College \& Research Libraries, 53(2), 176-181.

Plasmeijer, H. W. (2002). Pricing the serials library: in defence of a market economy. Journal of Economic Methodology, 9(3), 337-357.

ProQuest. (2021). Ulrichsweb global serials directory: Frequently asked questions (FAQs). Ann Arbor, MI: ProQuest. https://www.ulrichsweb.com/ulrichsweb/faqs.asp.

Quinn, B. A. (2001). The impact of aggregator packages on collection management. Collection Management, 25(3), 53-54.

Robinson, A. (2011). Societies and online journal models. Serials, 24(1), 56-59.

Rose-Wiles, L. M. (2011). The high cost of science journals: a case study and discussion. Journal of Electronic Resources Librarianship, 23(3), 219-241.

Shu, F., Mongeon, P., Haustein, S., Siler, K., Alperin, J. P., \& Larivière, V. (2018). Is it such a big deal? On the cost of journal use in the digital era. College \& Research Libraries, 79(6), 785-798.

Strieb, K. L., \& Blixrud, J. C. (2014). Unwrapping the bundle: an examination of research libraries and the "big deal." Portal: Libraries \& the Academy, 14(4), 587-615.

Taylor, A. (2013). Examination of work task and criteria choices for the relevance judgment process. Journal of Documentation, 69(4), 523-544.

van Ballegooie, M. (2016). Re-envisioning e-resource holdings management. The Serials Librarian, $70(1-4), 135-148$.

Walters, W. H. (2016). Beyond use statistics: Recall, precision, and relevance in the assessment and management of academic libraries. Journal of Librarianship and Information Science, 48(4), 340-352.

Walters, W. H. (2017). Citation-based journal rankings: key questions, metrics, and data sources. IEEE Access, 5, 22036-22053.

Walters, W. H. (2019). Beg, borrow, and steal: formal and informal access to the scholarly literature at U.S. master's universities. Journal of Academic Librarianship, 45(6), 102059.

Walters, W. H., \& Markgren, S. (2019). Do faculty journal selections correspond to objective indicators of citation impact? Results for 20 academic departments at Manhattan College. Scientometrics, 118(1), 321-337. 
Walters, W. H., \& Markgren, S. (2020). Zero-based serials review: an objective, comprehensive method of selecting full-text journal resources in response to local needs. Journal of Academic Librarianship, 46(5), 102189.

Walters, W. H., \& Markgren, S. (2021). Comparing the prices of commercial and nonprofit journals: a realistic assessment. Portal: Libraries and the Academy, 21(2), 389-410.

Waltham, M. (2010). The future of scholarly journal publishing among social science and humanities associations. Journal of Scholarly Publishing, 41(3), 257-324.

Wenzler, J. (2017). Scholarly communication and the dilemma of collective action: Why academic journals cost too much. College \& Research Libraries, 78(2), 183-200.

White, S., \& Creaser, C. (2004). Scholarly journal prices: Selected trends and comparisons. Loughborough, England: Loughborough University. https://www.lboro.ac.uk/microsites/infosci/lisu/downloads/op34. pdf.

White, S., \& Creaser, C. (2007). Trends in scholarly journal prices, 2000-2006. Loughborough, England: Loughborough University. https://www.lboro.ac.uk/microsites/infosci/lisu/downloads/op37.pdf. 